\title{
Laozi and Truman: A Hyperrealist Perspective
}

\author{
Aleksandar Stamatov \\ International College, Ming Chuan University, Taiwan \\ Email: astamat@yahoo.com
}

How to cite this paper: Stamatov, A. (2019). Laozi and Truman: A Hyperrealist Perspective. Open Journal of Philosophy, 9, 193-203.

https://doi.org/10.4236/ojpp.2019.92013

Received: April 10, 2019

Accepted: May 7, 2019

Published: May 10, 2019

Copyright (c) 2019 by author(s) and Scientific Research Publishing Inc. This work is licensed under the Creative Commons Attribution International License (CC BY 4.0).

http://creativecommons.org/licenses/by/4.0/ (c) (i) Open Access

\begin{abstract}
This paper will use the concept of hyperreality to compare the so-called ideal state described by ancient Chinese philosopher Laozi with the world of The Truman Show. The concept of hyperreality is defined by Jean Baudrillard as the generation by models of a real without origin or reality. A hyperreal world is a simulation, or kind of a copy without its original. It is generally accepted, and confirmed by Baudrillard himself, that the world of The Truman Show is hyperreal. In order to compare Laozi's ideal state with the world of the film, this paper will give a hyperrealist interpretation of the former, which will be only hypothetical, without intending to substitute any other existing interpretations. Laozi imagines that people live simple lives, with few desires and without traveling to other places. If we accept that the ideal state is a hyperreal world, we can make comparison between the two worlds; find out their similarities, as well as differences.
\end{abstract}

\section{Keywords}

Hyperreality, Laozi, Ideal State, The Truman Show

\section{Introduction}

The concept of hyperreality has been identified and discussed by scholars since the second half of the past century (Baudrillard, 1994; Deleuze, 1990; Eco, 1986). It is also evident that this concept is often used in cinematography, where it sometimes is contrasted to the reality as we know it. One of the many films that present a hyperreal world is The Truman Show (Peter Weir, 1998) in which the main character lives in a world imagined and created by a TV producer. In this essay the world of the film will be compared with the world of the so-called "ideal state" imagined by the ancient Chinese philosopher Laozi ${ }^{1}$. In order to get ${ }^{1}$ For transcription of the Chinese words and names, the Hanyu Pinyin system is used. The Chinese words in quotations are also adjusted to this system. The names of authors in References retain the original. 
the latter closer to Truman's world, this paper will use the concept of hyperreality as discussed by French philosopher Jean Baudrillard (1929-2007) and give a hypothetical hyperrealist interpretation of this ideal state. Thus, we can try to find out the similarities between the two worlds and also point out where they differ.

\section{Laozi's Ideal State}

Scholars today mostly agree that the book known as the Dao De Jing (The Classic of the Way and Its Excellence) $)^{2}$ was written probably at the end of the $4^{\text {th }}$ century BCE or earlier by an unknown author(s) for whom traditionally we are accustomed to use the name Laozi ${ }^{3}$. The book consists of 81 short chapters and, in total, contains about five thousand Chinese characters. It can be understood in different ways: as a mystical work, as a kind of religious work, or as a philosophical work including topics of metaphysics, ethics, and the art of governing. There may also be other types of interpretations but here we will confine ourselves to what belongs to the book's philosophy, especially its political philosophy and, more particularly, the ideal state ${ }^{4}$.

Laozi describes a rather small community with few people, who live simple lives and who would rarely or never travel to other places. The people are happy and satisfied with what they have, including their daily lives and customs, and they do not wish to have anything else. The technology they use for production and communication is not very developed, which does not cause any problems, but, on the contrary, makes their hearts peaceful and their lives content. Chapter 80 of the book describes this "ideal state" as follows:

Let there be a small country with few people.

Let there be ten times and a hundred times as many utensils

But let them not be used.

Let the people value their lives highly and not migrate far.

Even if there are ships and carriages, none will ride in them.

Even if there are armor and weapons, none will display them.

Let the people again knot cords and use them (in place of writing).

Let them relish their food, beautify their clothing, be content with their homes, and delight in their customs.

Though neighboring communities overlook one another and the crowing of cocks and barking of dogs can be heard,

Yet the people there may grow old and die without ever visiting one another. ${ }^{5}$

${ }^{2}$ Dao is usually translated as the Way, while De is sometimes translated as Power (Waley, 1997) or Virtue (Chan, 1973). Recently, Excellence is more preferred (Ames \& Hall, 2003).

${ }^{3}$ Further, this text will continue using the name Laozi as a name of a person, although we need to be aware that there are not enough historical data which verify the existence of such a person, as well as the authorship of the book that bares the same name.

${ }^{4}$ For more details on the book's origin, authorship, and content see Chan, 2001.

${ }^{5}$ All the quotations from Laozi are according to Chan, 1973. 
Superficially, we can say that this paragraph describes an ideal state or utopia. Actually, what can be first noticed here is that Laozi suggests that people should return to a certain past, when life was simpler and, by that, better. This kind of understanding is suggested by the classical interpreter of the Dao De Jing, Wang Bi (226-249), who says: "Even a small state with scanty population can return to the ancient, let alone the great state with plenty of people. Therefore the small state is used as an example" (Lin, 1992: p. 141). Although maybe Wang Bi's main point is that, if a small state can return to the antiquity, the big one can also do so, we can see that he takes for granted that in this passage an actual return is implied. But the question may be, what time does this return to the past signify? If we take it to be the primitive society, i.e. the one before the civilization, we can see that this does not apply, since in Laozi's small state there are tools and weapons, which means it is already civilized. Then, if it is not a return to the primitive society, maybe it is a return to a particular point of time in history; a nostalgia towards some peaceful golden age. Some scholars have accepted the idea that this state is actually a hope for the future ideal state, a kind of utopia. It is a fantasy that is not the same with the ideal; it is actually an idealized ideal. There is a contrast between the ideal and the real, but the contrast between the fantasy and the real is even stronger. Thus, as Laozi was unsatisfied with the current situation of the state and the government, he proposed an ideal state (Chen \& Bai, 2002: pp. 233-234).

However, it is acceptable to say that this paragraph represents a kind of metaphor. Some scholars have suggested that it is not a hope for an actual return to the primitive tribal life, or a hope for a future ideal state, but only an ideal in the heart of the author (Fu, 2003: p. 245). This would mean that Laozi probably only envisioned what an ideal state would look like, and it was only an idea in his mind, which he did not seriously try to advocate it or impose it to rulers.

In order to support this view, we can use the notion of the coherence of the text. It is obvious that the chapters of the Dao De Jing are disconnected from each other in such a way that the thought does not naturally flow from one chapter to another. Nevertheless, it contains to a certain degree coherent thought. That means that in order to understand a certain chapter we should not only dwell upon that chapter but try to find out whether other chapters can contribute to its understanding. In other words, we should avoid an isolated reading of the chapter (Shen, 2003: p. 360). Thus, treating Chapter 80 as a "constant utopian idea makes the text incoherent" (Hansen, 1992: p. 230). Or, we can even say that Laozi knew that his small state was unrealistic, but "imagining it may have helped him to formulate other elements of his political philosophy" (Roberts, 2001: p. 17). Strictly speaking, we have to consider particular chapters in the context of the whole text. In other places, we can see that Laozi speaks about a big country, too. And he does not dismiss it as worse than the small one. Could we then say that he really hopes the ideal state to be small? As an example, we can use an excerpt from Chapter 60:

Ruling a big country is like cooking a small fish. 
Another example is in Chapter 61:

A big country may be compared to the lower part of a river. ...

A big state can take over a small state if it places itself below the small state; And the small state can take over a big state if it places itself below the big state.

Here we can see that Laozi talks about a big state. In Chapter 60 he gives a kind of concrete advice on how to rule a big state, while in Chapter 61 he talks about relations between big and small states, which, in today's terms, could be called international relations. Since from these passages we can see that Laozi allows the existence of big states, to say that the Dao De Jing proposes that the state should really be small is not coherent with the text. The most we can say is that he imagines that the best state would be the one described in Chapter 80 and that it is only an idea in his heart or a metaphor. The author of this paper may say that he is closer to this standpoint, but that is not important here, because the aim is to try to compare Laozi's small state with the world of The Truman Show.

\section{The Truman Show}

The film is about a reality television show in which the main role is played by Truman Burbank (Jim Carrey), who is playing himself. Actually, he does not know that he is on TV and constantly under the observation of cameras. All the other people in the show are just actors. His parents, wife, and best friend are also actors. The surrounding consists of a small town called Seahaven particularly made for the show and resembles the USA of the 1950s. It looks like a utopia: everyone is friendly; everywhere is clean; everything is all right and so on. The creator of the show, Christof (Ed Harris), and his crew are placed in a studio above the town from where they direct the show. Truman is not aware that he is just a part of a television show until one day he starts noticing strange things and events, which make him suspect that something is wrong with his world.

The world of The Truman Show can be characterized as a hyperreality. This concept has been developed by French philosopher Jean Baudrillard in his famous work Simulacra and Simulation (1981). Baudrillard links hyperreality to the idea of simulation. Thus, "to simulate is to feign to have what one doesn't have" (1994: p. 3). He uses the fable from Jorge Luis Borges (1899-1986) in which "the cartographers of the Empire draw up a map so detailed that it ends up covering the territory exactly" (1994: p. 1). And, after the decline of the Empire the map also falls into ruins but some parts of it can be seen in the deserts. Thus, the territory no longer precedes the map; it is the map that precedes the territory. "Simulation is no longer that of a territory, a referential being, or a substance. It is the generation by models of a real without origin or reality: a hyperreal" (1994: p. 1). "It is no longer a question of imitation, nor duplication, nor even parody. It is a question of substituting the signs of the real for the real" (1994: pp. 1-2). 
The product of the simulation is called a simulacrum, which replaces reality with its representation, and can also be defined as "an image without resemblance" (Deleuze, 1990: p. 295). In other words, the hyperreal in a way simulates another reality and actually is kind of a copy of something that does not exist. It can also be described as the "absolute fake", which attempts to improve on reality itself (Eco, 1986).

The relation of the world of The Truman Show to hyperreality has been noted by Baudrillard himself, by recognizing that it is a film about the "growing blurring between the real and the virtual" (Coulter, 2010: p. 10); and others have also extensively written about it (Laist, 2015: pp. 141-150). My intention here is not to reflect upon what others have said about the hyperreality of the film, but to try to further examine its world by comparing it with Laozi's ideal state.

However, these two worlds are very different and, at first sight, it might seem that they do not have much in common. There may be several reasons to dismiss them as related in any way. First, they differ in time. Laozi's state is an ancient one, that is, pre-modern and pre-industrial. Truman's world is the modern and industrial, the one similar to ours. Second, they differ in geographical space. Laozi's world is that of China, Truman's that of the USA. Third, they differ in their purpose. Laozi's state is a political ideal, a description of the best state and government. The Truman Show is what the name itself says, a show: its purpose is to entertain the audience in front of their TV screens.

\section{Laozi and Hyperreality}

Since Laozi's state and The Truman Show are so different, maybe we can try to link them conceptually. As already stated above, the concept of hyperreality, as is described by Baudrillard, can be applied to Truman's world. Thus, we can try to apply it to Laozi's small state so that when they are both described as hyperreal worlds, we can have a good starting or linking point for their comparison. However, the purpose is not to give a substitute for the abovementioned or any other possible interpretations of the small state. Also, the intention is neither to claim that Laozi was aware of a concept similar to hyperreality, nor that ideas of it can be found in his book. All this linking of the ideal state to hyperreality should be taken hypothetically.

We can start with the Borges fable that Baudrillard uses to open his book. The map remains as the only referent to the territory that has gone. It itself is not that territory but actually it is the only reality that refers to that territory. The map is a copy of a reality that has been lost; it is a representation of something that does not exist: a hyperreality. Thus, if it is true that Laozi in Chapter 80 talks about a certain past which is lost, then this fable can perfectly be applied to it. That past age is gone and what remains as its referent is the small state that Laozi describes. So, the small state also represents something that does not exist and, by that, it is an imagination of a hyperreal world. Even if we accept the interpretation that the ideal state is only a metaphor, an idea in Laozi's mind or heart, it 
is still a copy without an original. Using Baudrillard's (1994: p. 6) words, this state has no relation to any reality whatsoever: it is its own pure simulacrum, that is, it is a product of simulation. On the basis of the above explanation, it seems that it is acceptable to allow that Laozi's ideal state is a kind of hyperreality.

As mentioned above, we cannot know whether Laozi talks about a certain time in the past. But what we can know is that he has in mind a certain human condition when lives were plain and simple (Ch. 19). So what Laozi says is that humans should return to the state of simplicity (Ch. 28). Actually, it seems that a great part of the project in the Dao De Jing is dedicated to finding out what the best political organization is ${ }^{6}$. The ideal state described in Chapter 80 is just one of the many statements related to this project. This political philosophy has its own metaphysical background and if we want to understand what the state of simplicity means, we need to turn to it now. This will help us to get better insight of the ideal state itself.

According to Laozi, there is an ontological principle responsible for the existence of the world which is called the Dao, or the Way (Ch. 4 and 25). However, we cannot really know the Dao and actually we do not know its real name so we just name it the Dao (Ch. 25). The very opening of the book also claims this:

The Dao that can be told of is not the eternal Dao (Ch. 1).

Thus, we cannot actually know the Dao, and we cannot give it a name. What we can give names to are the things around us because we can sense them, while Dao is out of our senses ${ }^{7}$. But what we can probably know is its function or manifestation in the world, which is called the De, or the Excellence. Dao gives birth to all things; De nourishes them (Ch. 51). The function of the Dao acts in a so-called natural way, which Laozi calls ziran and can be translated as self-so. Ziran is a kind of pattern or law and all things model on it (Ch. 25). However, it has to be noted that the Dao acts from its own pattern and its actions are not imposed from some outside force. Thus, to say that all things model on ziran is the same as to say that they follow the function of the Dao.

From this ontology we will turn to the realm of human beings, including governance. Laozi's idea is that society should also follow the function of the Dao, that is, its natural (ziran) working. But this ziran when applied to society and human beings gets another name, that is, wuwei. Literally, it is translated as no action; however, it is not mere passivity and doing nothing ${ }^{8}$. It is called this way ${ }^{6}$ Some scholars have indeed emphasized that the Dao De Jing is primarily a work on the art of government (Lau, 1963: pp. xxviii-xxix; Ames, 1994: p. 38; Hansen, 1992: p. 222).

${ }^{7} \mathrm{~A}$ classical interpretation is that "to call the Dao Dao, is not the same as to call a table table. When we call a table table, we mean that it has some attributes by which it can be named. But when we call the Dao Dao, we do not mean that it has any such namable attributes. It is simply a designation, or... Dao is a name which is not a name." (Fung, 1997: p. 95).

${ }^{8}$ As Chan explains, wuwei does not literally mean "inactivity", but rather "taking no action that is contrary to ziran" (1973: p. 136). In recent literature, there are different translations of wuwei which emphasize its active character, such as "noncoercive action" (Ames \& Hall, 2003) or "effortless action (Slingerland, 2003). The present author has previously discussed the problem of wuwei as a kind of action (Stamatov, 2014: p. 265; Stamatov, 2017: p. 129). 
in order to indicate the natural function of the Dao and thus it is distinguished from any unnatural actions or actions that are imposed on humans. Laozi himself confirms that this is a kind of action by putting one more wei in front of it, becoming wei wuwei, acting without acting (Ch. 3 and 63). The point is that even with wuwei everything will be done, that is, there will be nothing left undone (Ch. 37 and 48).

The state in which human beings live according to wuwei is plain and simple. Returning to the state of plainness and simplicity means returning to the following of the natural operation of the Dao. But humans cannot do that by themselves. They need someone who can lead them to this state. We can see that Laozi usually, if not always, relates the term wuwei to the sage. The sage is a person who understands the natural working of the Dao, i.e. ziran, and knows how to apply wuwei in society. In other words, the sage should be the ruler. Since the sage-ruler uses wuwei, his actions only follow the natural function of the Dao. By this, he does not reveal his existence to the people; he puts himself in the back, but his actions come out in the front (Ch. 7). Hence, he is not a person who would like to be very well-known, and the people think that everything that is done is done by themselves following ziran (Ch. 17). However, it is the sage-ruler who takes care of all the matters in the society ${ }^{9}$ while the people only believe that everything is achieved by themselves alone. Thus, Laozi stresses that by acting without acting (wei wuwei) everything will be in order (Ch. 3).

There is, of course, more to say and deeper to go, but hopefully this should be enough for a general outline of Laozi's philosophy and a basic understanding of his political philosophy in particular. This would help us see that the ideal state that Laozi describes is a state in which people live according to the natural operation of the Dao; in short, a Daoist state. The basic assumption of this political philosophy is that human beings have lost their original nature, which is plain and simple and comes from the Dao. Today, as in Laozi's time, they do not live by wuwei but by deliberate actions which do not follow the natural function of the Dao. If we hope that human beings will return to their original state or if we only imagine that they may return, it reminds us again of what Baudrillard says about some primitive tribes in the Philippines and North America (Baudrillard, 1994: pp. 7-8). These people have been taken out of their primitive state and received the influence of the civilization that "discovered" them. In other words, their original nature is lost and there may only be some memory left of it. Upon the decision to bring them back to their primitive state, so that they can return to their original nature, they become "the model of simulation" (1994: p. 8) of all of their ancestors. The case with Laozi's small state may not totally resemble the situation Baudrillard describes. While in the former case we have only part of the humanity returning to their original nature, Laozi, as is evident from what is ${ }^{9}$ It is a common opinion that the sage-ruler is not to interfere in the people's natural lives, that is, lives according to the Dao. This statement is not incorrect as long as it is taken to mean that the sage-ruler is someone who takes care that people keep their natural lives. As Schwartz points out, Laozi imagined a state of affairs brought about by a sage-ruler (Schwartz, 1985: p. 213). See also Stamatov, 2014: pp. 272-273. 
explained above, talks about the whole humanity. On the basis of the idea of a return to the past, it seems acceptable to agree that there is a striking similarity between the two cases.

\section{Laozi and Truman}

If we accept this hyperrealist explanation of Laozi, which is not intended to give another new interpretation of its philosophy or a part of it, but is taken only hypothetically in order to help us compare the ideal state with Truman's world, we can agree that there are some similarities between the two. The first thing that we may allow is that, in general, both worlds are hyperreal. They are both representations of something that does not really exist, or they are simulated realities. What they both represent are sort of ideal worlds, or worlds we may desire for us or we may wish to live in. In these ideal worlds everything seems all right and people could not wish anything else for themselves. They are imagined as if they are satisfied with their lives and they are not supposed to be interested about what is going on outside their communities. However, there are two important differences here. First, Laozi imagines that it is the reality for all the people in the small state, while in The Truman Show that reality is only for one person, Truman himself. All the other people in Seahaven know that it is a simulation, while for Truman it is the reality. And, second, while the people in the small state are happy living their simple lives, Truman seems to be constrained by such simplicity and feels unhappy. He wants to explore and engage in adventures, and to travel to Fiji on the other side of the world. Maybe the producer imagined the character of Truman to live a simple and happy life, but it turned out that he was unsatisfied with such a life.

There are similarities in some particular points, too. We can see that people in the small state and Truman in his own town are not supposed to travel outside their habitats. There are transportation options in Laozi's ideal state, but no one uses them. This is because people's lives are made plain and simple so they do not need to go abroad. Similarly, there are also transportation options in Seahaven, but Truman is not encouraged to leave his hometown and, certainly, he is not allowed to do so if the show is to continue. As a child, he said he wanted to sail and explore the world, so the producers had to fake his father's drowning in the sea while sailing together, which caused him get aquaphobia. Since that day he could not sail again or get on a boat. Also, broadcasting and messages of accidents while traveling can be seen all around the town. When he finally decides to go on a trip, the travel agent tells him that all the flights in the next month are booked; the bus he gets on breaks down before even it can depart; and getting on a boat is still out of question. When he decides to leave the town by car, all the roads are suddenly jammed, and when he does manage to leave it, the producer comes up with more creative ways to stop his journey, such as a forest fire and nuclear accident.

Moreover, both Laozi's state and Truman's world are subject to rule or con- 
trol. In the case of Laozi, we have seen that there is a sage-ruler who tries to maintain people's lives in accordance with the natural function of the Dao. And we have also seen that the characteristic of this ruler is not to show off his appearance or existence. Thus, people think that everything that is done to achieve happy and peaceful lives is done by themselves. Similarly, Truman does not know that this is a show and that it has a director and a producer. Christof is far from being a sage in the Daoist meaning, and especially he is not a ruler or a leader of a country, but he nonetheless sits hidden in his studio and, with the help of his employees, controls the life of Seahaven. Truman most probably thinks that he is free to make decisions for himself, while actually most of his life and interaction with other people are directed from that studio.

Another concept from Laozi that can be applied to Truman's world is the so-called ignorance. In Chapter 3 , it is said that people in the state governed by the sage have no knowledge or desires. Here is the full passage:

Do not exalt the worthy, so that the people shall not compete.

Do not value rare treasures, so that the people shall not steal.

Do not display objects of desire, so that the people's hearts shall not be disturbed.

Therefore in the government of the sage,

He keeps their hearts vacuous,

Fills their bellies,

Weakens their ambitions,

And strengthen their bones,

He always causes his people to be without knowledge or desire,

And the crafty to be afraid to act.

By acting without action, all things will be in order.

It is the knowledge and desire for unnecessary items that might interfere with the people's peaceful hearts and cause them depart from the natural lives according to the Dao. Similar ideas can be seen in Chapter 65:

In ancient times those who practiced Dao well

Did not seek to enlighten the people, but to make them ignorant.

People are difficult to govern because they have too much knowledge.

Knowledge is related to desires and actually what these passages talk about is diminishing desires. Living plain and simple lives, that is, lives in accordance with the natural operation of the Dao, means that people are not overcome by their desires. They only have the natural desires for preservation and continuation of their lives. So, they are kept ignorant of other desires, such as desires for rare treasures or other objects that bring momentary pleasures. These desires might endanger the Daoist society. Once they pop up, it may cause problems for the sage to continue keeping the people in a state of simplicity, although he still seems to be an optimist since Chapter 37 says:

Dao invariably takes no action, and yet there is nothing left undone. 
If kings and barons can keep it, all things will transform spontaneously.

If, after transformation, they should desire to be active,

I would restrain them with simplicity, which has no name.

Simplicity, which has no name, is free of desires.

Being free of desires, it is tranquil.

And the world will be at peace of its own accord.

The sage will try to restrain people's desires and bring them back to following the natural course of the Dao. So, in order for people to continue living their plain and simple Daoist lives, they have to remain ignorant of their unnecessary desires. They are aware of the existence of other communities, weapons and transportation, but they do not desire to travel or fight. Actually, they do not think they need to.

Truman is in a kind of similar situation. However, his ignorance is not the ignorance of desires, but ignorance of the whole situation which he is in. Christof also needs to take care that he stays in the state of ignorance, because this is the only way that the show can go on. But as soon as he starts getting out of his ignorance, Christof has troubles running the show. As mentioned above, when Truman tries to travel, all the ways of getting out of Seahaven are blocked. His suspicion about his world grows bigger and bigger so that eventually he realizes the situation in which he is placed. He decides to leave his city by sea, sailing, in accordance with his childhood wish, thus overcoming the aquaphobia. Cristof unsuccessfully tries to stop him with a very severe storm, almost killing him. At the end, Truman arrives at the wall of his world where a gate opens which can take him to the "real" world and Christof tries to convince him to stay in the show. He is maybe as optimistic as Laozi's sage, but he fails; Truman chooses to cross the gate.

\section{Conclusion}

In the above, this paper compared Laozi's ideal or small state with the world of The Truman Show. It used the concept of hyperreality, as defined by Baudrillard, to get these two worlds closer to each other. Laozi's ideal state was interpreted as a hyperreal world, but this was taken only hypothetically, without trying to substitute the existing theories or interpretations of it. Thus, the paper pointed out some similarities between the two but it was also aware of the crucial differences. In general, we may accept that both worlds have something in common, which is that they represent a kind of hyperreality; each of them is a simulation of a reality, a copy of a world that does not exist. In some particular points we can see that people in the small state are neither supposed nor encouraged to travel outside it and similarly Truman is not encouraged and actually not allowed to travel outside his own town. Both the small state and Seahaven are subject to control, the former by a ruler, the latter by a producer. And both people in the small state and Truman in Seahaven are kept in ignorance; the former in ignorance of their unnecessary desires, the latter in ignorance of 
what actually is going on.

\section{Conflicts of Interest}

The author declares no conflicts of interest regarding the publication of this paper.

\section{References}

Ames, R. T., \& Hall, D. L. (2003). Daodejing_ "Making This Life Significant": A Philosophical Translation. New York: Balantine Books.

Ames, R. T. (1994). The Art of Rulership: A Study of Ancient Chinese Political Thought. New York: State University of New York Press.

Baudrillard, J. (1994). Simulacra and Simulation. Ann Arbor, MI: The University of Michigan Press. https://doi.org/10.3998/mpub.9904

Chan, A. (2001, substantive revision 2013). Laozi. Stanford Encyclopedia of Philosophy. https://plato.stanford.edu/entries/laozi/

Chan, W.-T. (Transl. \& Comp.) (1973). A Source Book in Chinese Philosophy. Princeton, NJ: Princeton University Press.

Chen, G., \& Bai, X. (2002). Laozi Pingchuan (A Commentary on Laozi). Taipei: Wenshizhe.

Coulter, G. (2010). Jean Baudrillard and Cinema: The Problems of Technology, Realism and History. Film-Philosophy, 14, 6-20. https://doi.org/10.3366/film.2010.0041

Deleuze, G. (1990). The Logic of Sense. New York: Columbia University Press.

Eco, U. (1986). Travels in Hyperreality. Orlando FL: Harcourt Brace Jovanovich Inc.

Fu, P. (2003). Jiedu Laozi (Reading Laozi). Taipei: Lixu Wenhua.

Fung, Y.-L. (1997). A Short History of Chinese Philosophy. New York: The Free Press.

Hansen, C. (1992). A Daoist Theory of Chinese Thought: A Philosophical Interpretation. New York: Oxford University Press.

Laist, R. (2015). Cinema of Simulation: Hyperreal Hollywood in the Long 1990s. London: Bloomsbury Academic.

Lau, D. C. (1963). Lao Tzu: Tao Te Ching. New York: Penguin.

Lin, P. J. (Transl.) (1992). A Translation of Lao Tzu's Tao Te Ching and Wang Pi's Commentary. Ann Arbor, MI: Center for Chinese Studies.

Roberts, M. (Transl.) (2001). Laozi Dao De Jing: The Book of the Way. Berkeley, CA: University of California Press.

Schwartz, B. (1985). The World of Thought in Ancient China. Cambridge, MA: The Belknap Press of Harvard University Press.

Shen, V. (2003). Laozi (Lao Tzu). In A. S. Cua (Ed.), Encyclopedia of Chinese Philosophy (pp. 355-361). New York and London: Routledge.

Slingerland, E. (2003). Effortless Action: Wu-Wei as Conceptual Metaphor and Spiritual Ideal in Early China. Oxford: Oxford University Press.

Stamatov, A. (2014). The Laozi and Anarchism. Asian Philosophy, 24, 260-278. https://doi.org/10.1080/09552367.2014.960296

Stamatov, A. (2017). The Laozi's Criticism of Government and Society and a Daoist Criticism of the Modern State. Asian Philosophy, 27, 127-149.

https://doi.org/10.1080/09552367.2017.1319782

Waley, A. (Transl.). (1997). Lao Tzu Tao Te Ching. Hertfordshire: Wordsworth Editions. 